\title{
KARAKTERISTIK OSEANOGRAFI DAN KELIMPAHAN FITOPLANKTON DI PERAIRAN SELAT SUNDA PADA MUSIM TIMUR
}

\section{OCEANOGRAPHYCAL CHARACTERISTIC AND PHYTOPLANKTON ABUNDANCE IN SUNDA STRAIT WATERS IN EAST MONSOON}

\author{
Khairul Amri, Asep Priatna dan Suprapto \\ Peneliti pada Balai Penelitian Perikanan Laut, Muara Baru-Jakarta \\ Teregistrasi I tanggal: 04 Januari 2013; Diterima setelah perbaikan tanggal: 03 April 2014; \\ Disetujui terbit tanggal: 07 April 2014 \\ E-mail:kh_amri@yahoo.com
}

\begin{abstract}
ABSTRAK
Selat Sunda merupakan salah satu perairan yang penting dalam sirkulasi massa air di Indonesia. Dinamika oseanografinya dipengaruhi massa air Laut Jawa dan Samudera Hindia. Tujuan penelitian ini adalah mengkaji karaktersitik oseanografi (suhu, salinitas, arus dan kecerahan) dan kelimpahan fitoplankton di Selat Sunda. Penelitian dilakukan bulan Juni-Juli 2010 (musim timur). Hasil penelitian menunjukkan nilai sebaran suhu dan salinitas bervariasi, terkait pengaruh massa air yang dominan. Pada area mendekati pesisir barat Banten suhu lebih hangat dan salinitas lebih rendah, terkait pengaruh daratan (river discharge) dan aliran massa air dari Laut Jawa. Indikasi upwelling ditemukan di daerah tubir sebelah selatan Selat Sunda, disebabkan benturan arus kuat Samudera Hindia. Pada bulan Juni-Juli intensitasnya masih lemah, menandakan fase awal dari proses terjadinya upwelling di perairan ini. Nilai indeks keanekaragaman dan keseragaman fitoplankton yang tertinggi berasosiasi dengan lokasi upwelling. Terdapat korelasi yang kuat antara peningkatan konsentrasi kesuburan perairan akibat terjadinya upwelling pada musim timur dengan hasil tangkapan ikan pelagis. Jenis ikan yang dominan tertangkap musim timur adalah kelompok ikan pelagis kecil oseanik.
\end{abstract}

KATA KUNCI: Oseanografi, fitoplankton, Selat Sunda, musim timur

\section{ABSTRACT}

The Sunda strait is an importance area of Indonesian troughflow. The dynamic oceanographyc of this waters is influenced by Java Sea and Indian Ocean water mass. The objectives of this study to known the physical oceanographyc parameters (temperature, salinity, current and turbidity) and biology aspect (phytoplankton abundance) by analyize used in-situ data. The study were canied out June to July 2010 (east monsoon). The result showed that variability of temperature and salinity related to kind of dominan water masses. The high temperature and low salinity founded in western part of Banten waters, its rivers discharge and Java Sea waters influenced. The low upwelling intensity is finded in the slope area, caused by strong flow from Indian Ocean as indicated fre-phase of upwelling process in this water. The diversity index and evenness index with high value is associated with upwelling area. There is a stong correlation betwen elevated coneentrations of primary productivity due to upwelling in the east monsoon with an inerease in pelagic fish catches. The dominant species of fish caught in east monsoon was oceanic small pelagic fish group.

\section{KEYWORD: Oceanographyc, phytoplankton, Sunda Strait waters, east monsoon}

\section{PENDAHULUAN}

Ditinjau dari aspek oseanografi, Selat Sunda merupakan salah satu perairan yang penting dalam sirkulasi massa air di Indonesia. Dinamika massa airnya dipengaruhi oleh aliran dua massa air utama, yaitu massa air Laut Jawa di bagian sebelah utara dan massa air Samudera Hindia di bagian selatan. Pencampuran kedua massa air tersebut berdampak positif terhadap kualitas massa air Selat Sunda, antara lain berpengaruh terhadap kandungan zat hara (nutrien), klorofil, fitoplankton dan suspended solid/ seston (Adnan, 2003). Perairan Selat sunda merupakan perairan yang sangat dinamis dan dipengaruhi oleh sistem arus di Laut Jawa dan Samudera Hindia. Fenomena- fenomena lokal seperti musim dan aktivitas vulkanologi yang ada di Selat Sunda juga sangat berpengaruh terhadap karakteristik oseanografi di perairan tersebut.

Suhu merupakan parameter lingkungan yang paling sering diukur di laut karena berguna dalam mempelajari proses fisika, kimia, dan biologi yang terjadi di laut. Pola distribusi suhu permukaan laut dapat digunakan untuk mengidentifikasi parameter-parameter oseanografi lain seperti arus, umbalan dan front (Pralebda \& Suyuti, 1983). Tisch et al. (1992) mengatakan perubahan kondisi suatu massa air dapat diketahui dengan melihat sifat-sifat massa air seperti salinitas, oksigen terlarut, dan kesuburan 
perairan. Nontji (1987) menyatakan suhu air laut merupakan faktor yang banyak mendapat perhatian dalam pengkajian kelautan. Data suhu dapat dimanfaatkan bukan saja untuk mempelajari gejala fisika di dalam laut, tetapi juga kaitannya dengan kehidupan hewan atau tumbuhan. Pada dasarnya suhu air laut dipengaruhi panas matahari yang diterima lapisan permukaan air laut. Selain faktor tersebut, faktor lain yang mempengaruhinya adalah arus permukaan, keadaan awan, penguapan, gelombang pergerakan konveksi, upwelling, divergensi dan konvergensi terutama pada daerah estuari dan sepanjang pantai (Laevastu \& Hayes, 1981).

Beberapa penelitian mengenai aspek oseanografi di Selat Sunda antara lain dikemukakan Birowo et al. (1981); Birowo (1983); dan Muripto et al. (2000) Sementara Hasyim et al. (1995); Hendiarti et al. (2005) dan Amri et al. (2006) mengkombinasikan pengamatan kondisi oseanografi Selat Sunda antara data in-situ dengan citra satelit. Tulisan ini membahas karakteristik oseanografi dan kelimpahan fitoplankton Selat Sunda khususnya di bagian paparan berdasarkan data in-situ pada musim timur (Juni-Juli) 2010 dan diperkaya dengan data referensi terkait parameter lainnya.

\section{BAHANDANMETODE}

\section{Lokasi dan Waktu Penelitian}

Lokasi penelitian terdapat di perairan Selat Sunda posisi geografis antara $\left(05.00 .00^{\circ} \mathrm{LS}-07.00 .00^{\circ} \mathrm{LS}\right.$ dan $\left.104.00 .00^{\circ} \mathrm{BT}-106.30 .00^{\circ} \mathrm{BT}\right)$ dengan 25 stasiun pengukuran parameter oseanografi (fisika dan biologi) seperti tertera pada Gambar 1.
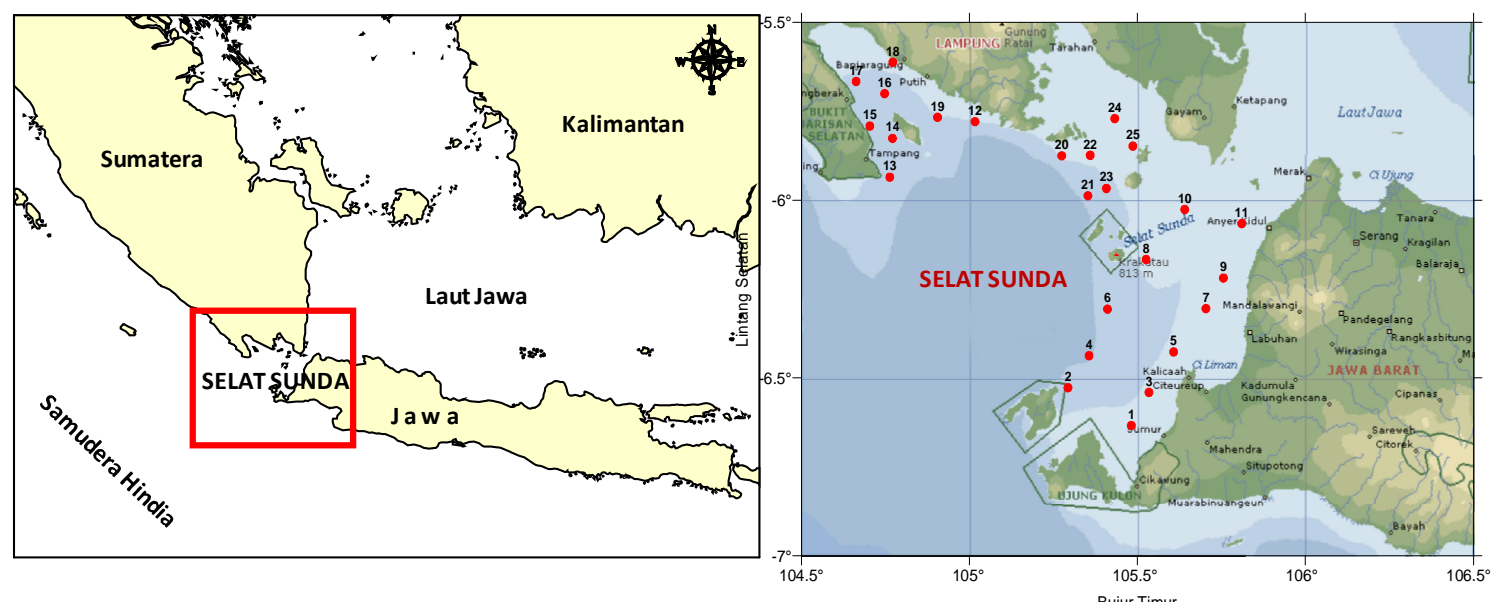

Gambar 1. Peta lokasi penelitian (kiri) dan posisi stasiun pengukuran parameter oseanografi (kanan) di Selat Sunda Figure 1. Map showing of sampling site (left) and the position of oceanographyc measurement (right)in Sunda Strait waters

Stasiun oseanografi terdapat di perairan barat Banten (Stasiun 1, 2, 3, 4, 5, 6, 7, 8, 9,10 dan 11) Teluk Semangka (Stasiun 12, 13, 14, 15, 16, 17, 18, dan 19) dan sekitar gugusan Pulau Rakata (Stasiun 20, 21, 22, 23, 24, dan 25). Penelitian dilaksanakan selama 10 hari, mulai 26 Juni - 5 Juli 2010, mewakili musim timur.

\section{METODE}

Penelitian dilakukan dengan metode survei eksploratif menggunakan kapal riset "KR Sardinella”, Balai Penelitian Perikanan Laut (BPPL). Data oseanografi diperoleh dengan menggunakan instrument Conductivity Temperature Depth (CTD) Profiler Valeport 308 dan CTDcurrent meter Valeport type 108/308. Pengukuran kecerahan air laut dilakukan menggunakan sechi dish. Parameter oseanografi fisik yang diambil meliputi suhu, salinitas, arah dan kecepatan arus. Perangkat CTD diturunkan mulai dari permukaan sampai kedalaman maksimum 5 meter sebelum dasar laut (tergantung kedalaman perairan). Data suhu, salinitas, arah dan kecepatan arus, dan kedalaman diperoleh setiap interval 5 detik. Data hasil pengukuran dipindahkan (upload) ke dalam perangkat komputer menggunakan software DataLog untuk analisis selanjutnya berupa profil menegak, sebaran vertikal dan horizontal tiap strata kedalaman. Aspek biologi oseanografi yang dikaji adalah kelimpahan fitoplankton, diperoleh dengan cara menyaring air menggunakan plankton net. Spesifikasi fitoplankton net yang digunakan yaitu diameter mulut jaring $31 \mathrm{~cm}$, panjang jaring $100 \mathrm{~cm}$ dan ukuran mata jaring 0,08 mm. Fitoplankton net dioperasikan secara horizontal pada permukaan laut dengan jarak towing $25 \mathrm{~m}$. Ukuran zooplankton net adalah diameter mulut jaring $45 \mathrm{~cm}$, panjang jaring $180 \mathrm{~cm}$ dan ukuran mata jaring $0,3 \mathrm{~mm}$, dan dioperasikan secara vertikal sampai kedalaman $20 \mathrm{~m}$. Setiap sampel plankton diawetkan dengan formalin $4 \%$ dalam masing-masing botol sampel $100 \mathrm{ml}, 250 \mathrm{ml}, 500 \mathrm{ml}$. Kemudian dilakukan pencacahan 
dan penghitungan menggunakan mikroskop binokuler. Identifikasi jenis plankton, mengacu Yamaji (1979) dan Thomas (1997). Hasil penghitungan kemudian dianalisis lebih lanjut untuk memperoleh komposisi dan kelimpahan fitoplankton serta indeks kaeanekaragaman (indeks keragaman, indeks kemerataan dan indeks dominansi jenis) yang mengacu pada Ludwig \& Reynold (1988):

a) Indeks kekaragaman jenis "Shannon-Wiener", seperti dikutip Odum (1971) dengan rumus : $H^{\prime}=-$ å $\left[\left(\mathbf{n}_{\mathrm{i}} / \mathbf{N}\right)\right.$ / $\mathbf{L n}\left(\mathbf{n}_{\mathrm{i}} / \mathbf{N}\right)$ ] dimana $\mathbf{N}=$ total plankton (individu atau sel) untuk semua spesies, dan $\mathbf{n}_{\mathbf{i}}=$ jumlah plankton (individu atau sel) untuk spesies ke- $i$.

b) Indeks kemerataan dihitung adalah indeks menurut Pielou (1976) dengan rumus $\mathbf{E}_{\mathbf{1}}=\mathbf{H}^{\prime} / \mathbf{L n}$ (s), dimana $S$ = banyaknya spesies, H'= indeks Shannon-Wiener,

c) Indeks dominansi jenis dengan rumus $\mathrm{C}=\sum\left[\frac{\mathrm{n}_{\mathrm{i}}}{\mathrm{N}}\right]^{2}$ dimana $\mathrm{n}_{\mathrm{i}}=$ jumlah plankton (individu atau sel) untuk spesies ke $i$. $\mathrm{N}=$ jumlah total plankton (individu atau sel) semua spesies.

\section{HASIL DAN BAHASAN}

HASIL

\section{Profil Menegak Suhu dan Salinitas}

Profil menegak suhu dan salinitas di perairan barat Banten bagian pesisir dan tengah menunjukkan nilai yang bervariasi, akibat pengaruh masukan air dari sungai (river discharge) (Gambar 2). Pada beberapa stasiun oseanografi, dimana perairannya dipengaruhi run off dari daratan, umumnya mempunyai nilai suhu tinggi dan salinitas yang rendah. Sementara pada lapisan yang lebih dalam, suhu dan salinitas relatif stabil mengingat area tersebut merupakan perairan dangkal. Profil menegak suhu dan salinitas di perairan Teluk Semangka dan gugusan Pulau Rakata menunjukkan pola yang berbeda dengan di perairan pesisir Banten (Gambar 3). Pada perairan yang dangkal, suhu dan salinitas relatif konstan di semua strata akibat pengadukan air oleh arus yang cukup kuat. Pada perairan yang lebih dalam, lapisan termoklin terdeteksi pada kedalaman 50-150 m. Lapisan termoklin pada area yang diamati cukup kuat dimana rata-rata perubahan suhu terhadap kedalaman (gradien suhu) sekitar $0,1{ }^{\circ} \mathrm{C} / \mathrm{m}$. Sebaliknya untuk salinitas, terjadi perubahan salinitas yang cukup drastis terhadap pertambahan kedalaman pada strata permukaan sampai $50 \mathrm{~m}$, menunjukkan bahwa kedua perairan ini mendapat pengaruh massa air oseanik dari Samudera Hindia.

\section{Sebaran Melintang Suhu dan Salinitas}

Analisa sebaran melintang suhu dan salinitas, menunjukkan pada area pesisir barat Banten, dimana kedalamannya lebih dangkal dibanding bagian tengah, memiliki suhu dan salinitas cenderung homogen. Hal ini menunjukkan terjadinya pengadukan yang merata secara vertikal. Sementara kondisi suhu dan salinitas pada area tengah yang lebih dalam, pelapisan atau strata massa air terlihat jelas. Lapisan homogen terlihat sampai kedalaman $50 \mathrm{~m}$, sementara lapisan termoklin berada di bawahnya dengan fluktuasi temperatur sekitar $0,1{ }^{\circ} \mathrm{C} / \mathrm{m}$. Sebaran melintang suhu dan salinitas seperti terlihat pada Gambar 4, menunjukkan adanya dorongan massa air dari selatan yang berasal dari Samudera Hindia di area tengah, dibuktikan dengan suhu rendah dan salinitas tinggi yang mengarah ke arah dalam selat.

\section{Sebaran Mendatar Suhu dan Salinitas Permukaan}

Sebaran mendatar suhu dan salinitas permukaan pada bulan Juni-Juli yang bertepatan dengan musim timur, seperti terlihat pada (Gambar 5), menunjukan suhu permukaan laut (SPL) di perairan barat Banten lebih tinggi dari pada area lainnya. Rata-rata SPL pada perairan barat Banten sekitar $30^{\circ} \mathrm{C}$, suhu permukaan terendah ditemukan di perairan Teluk Semangka bagian dalam dengan ratarata suhu $29{ }^{\circ} \mathrm{C}$. Sementara suhu permukaan di sekitar gugusan Pulau Rakata sekitar $29,3{ }^{\circ} \mathrm{C}$. Kondisi sebaliknya terjadi untuk parameter salinitas, dimana salinitas permukaan di perairan barat Banten lebih rendah dari pada area lainnya yaitu sekitar 32,1 ppt. Salinitas permukaan tertinggi ditemukan di perairan Teluk Semangka dengan nilai rata-rata 33,5 ppt dengan salinitas permukaan di sekitar gugusan Pulau Rakata sekitar $32,5^{\circ} \mathrm{C}$. 

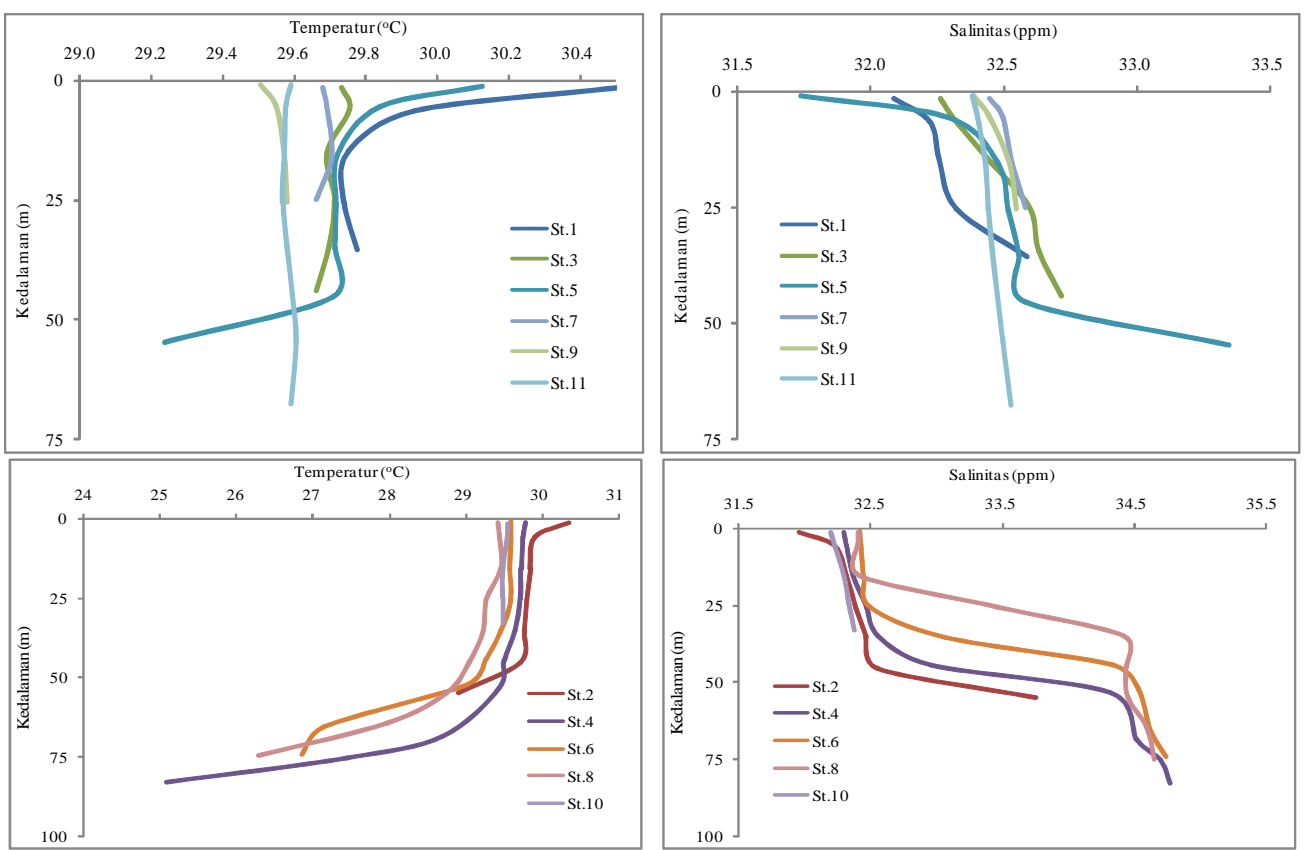

Gambar 2. Profil menegak suhu dan salinitas di perairan barat Banten bagian pesisir (atas) dan bagian tengah (bawah) pada bulan Juni-Juli 2010

Figure 2. Vertical profile of temperature and salinity in coastal waters area of western part of Banten (above) and off shore area (below) on June-July, 2010
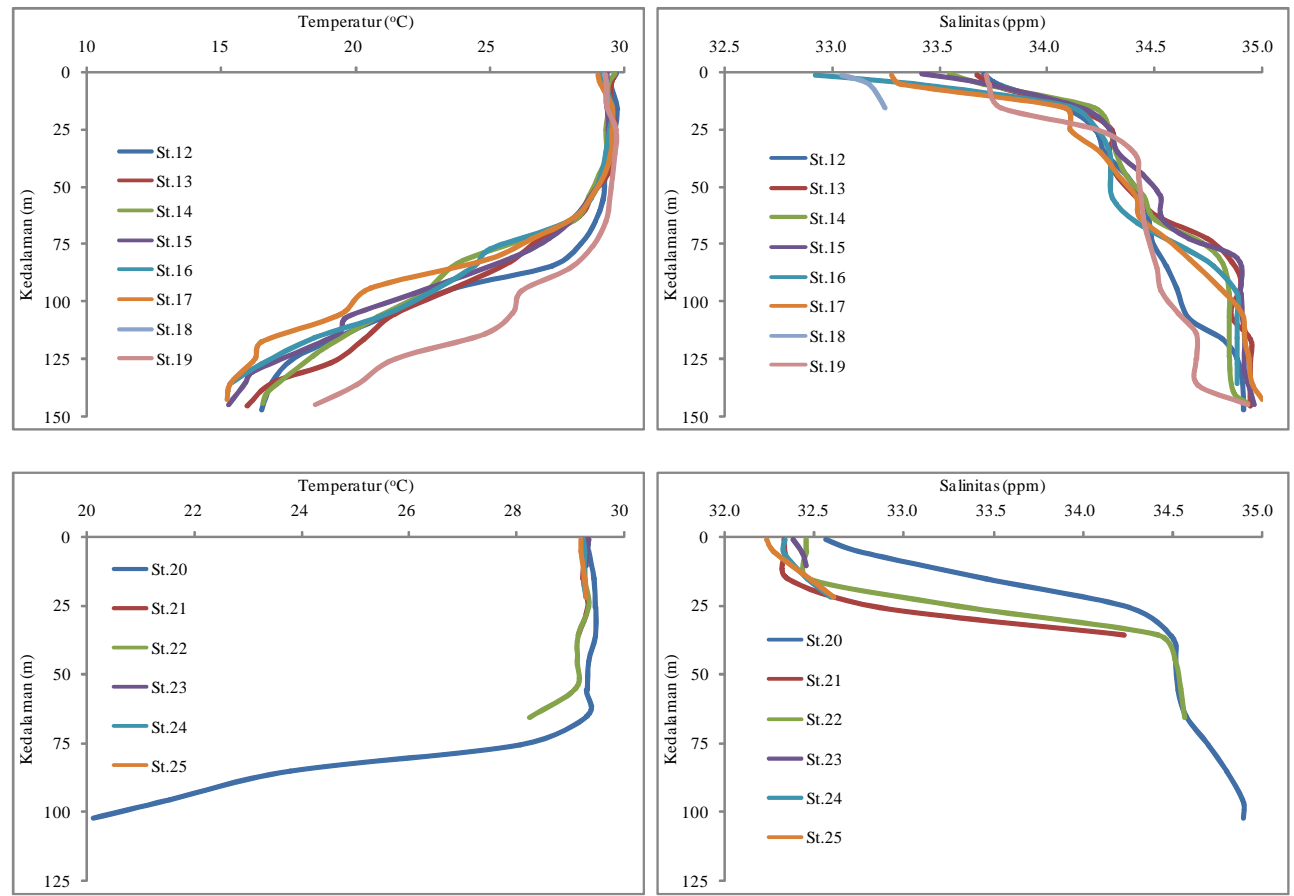

Gambar 3. Profil menegak suhu dan salinitas di perairan Teluk Semangka (atas) dan gugusan Pulau Rakata (bawah) pada bulan Juni-Juli 2010

Figure 3. Vertical profile of temperature and salinity in the Teluk Semangka waters (above) and Rakata islands waters (below) on June-July, 2010 

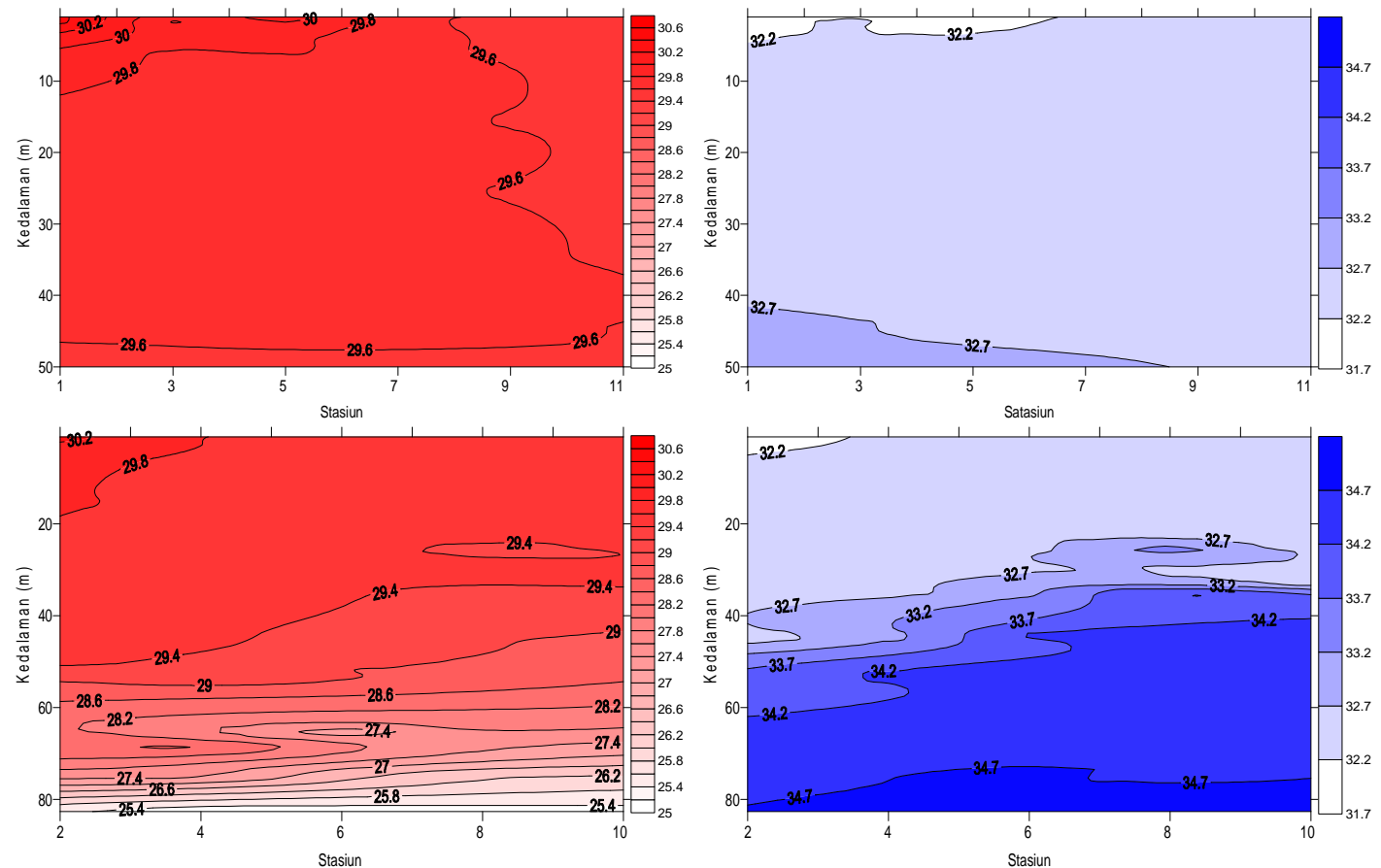

Gambar 4. Sebaran melintang suhu dan salinitas di bagian timur (atas) dan bagian tengah dari Selat Sunda (bawah), Juni-Juli 2010

Figure 4. Transverse distribution of temperature and salinity in eastern part of Sunda Strait waters (above) and center area of Sunda Strait waters (below) on June-July, 2010
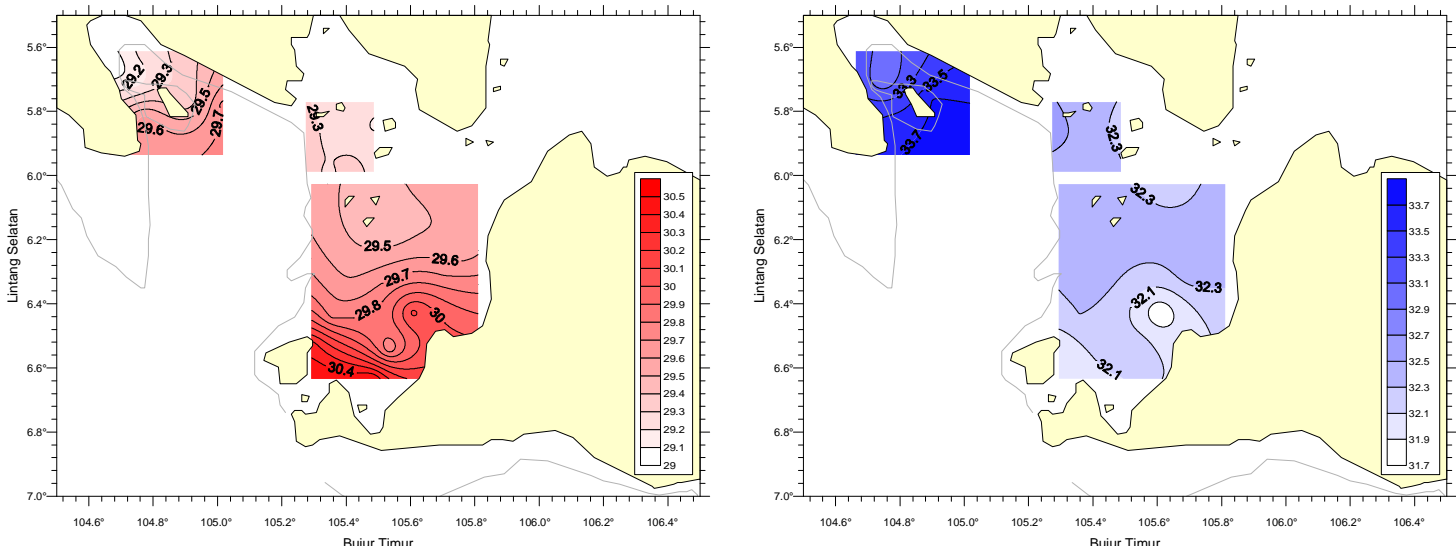

Gambar 5. Pola sebaran mendatar suhu (kiri) dan salinitas (kanan) permukaan perairan Selat Sunda pada bulan JuniJuli 2010

Figure 5. Horizontal distribution of surface temperature (left) and salinity (right) in Sunda straits waters on June-July, 2010

\section{Arus dan Nilai Kecerahan}

Arah dan kecepatan arus pada musim timur di perairan Selat Sunda pada setiap strata kedalaman yang diukur disajikan pada Gambar 6. Secara umum terlihat bahwa kecepatan arus pada lapisan dalam lebih kuat dari pada arus di bagian permukaan dan dominan berasal dari Samudera Hindia. Arus yang berasal dari Laut Jawa terlihat berada pada sisi perairan pantai Banten (Carita, Labuhan sampai Tanjung Lesung) menuju Selatan dan Barat Daya, dan di sekitar perairan Pulau Panaitan arus ini dibelokkan ke arah Utara dan Barat Laut. Diduga pengaruh yang kuat dari dorongan massa air Samudera Hindia di bagian selatan selat. Nilai kecerahan perairan hasil pengukuran sechi dish disajikan pada Tabel 1. Pengukuran kecerahan hanya dilakukan pada siang hari, sehingga pada beberapa posisi stasiun yang bertepatan waktu malam hari pengukuran tidak dilakukan. Tinggi rendahnya kecerahan air laut 
sangat ditentukan kekeruhan air karena partikel tersuspensi dan kedalaman perairan. Kelimpahan fitoplankton yang tinggi juga menyebabkan rendahnya kecerahan suatu perairan. Umumnya stasiun yang berada pada perairan dekat pantai tingkat kecerahannya lebih rendah, terutama di pesisir barat Banten. Sebaliknya stasiun yang lebih ke arah selatan tingkat kecerahannya lebih tinggi.

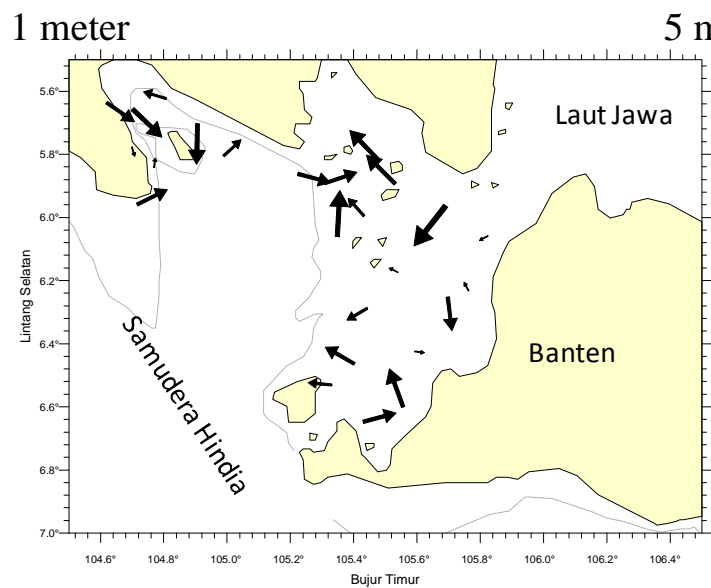

meter
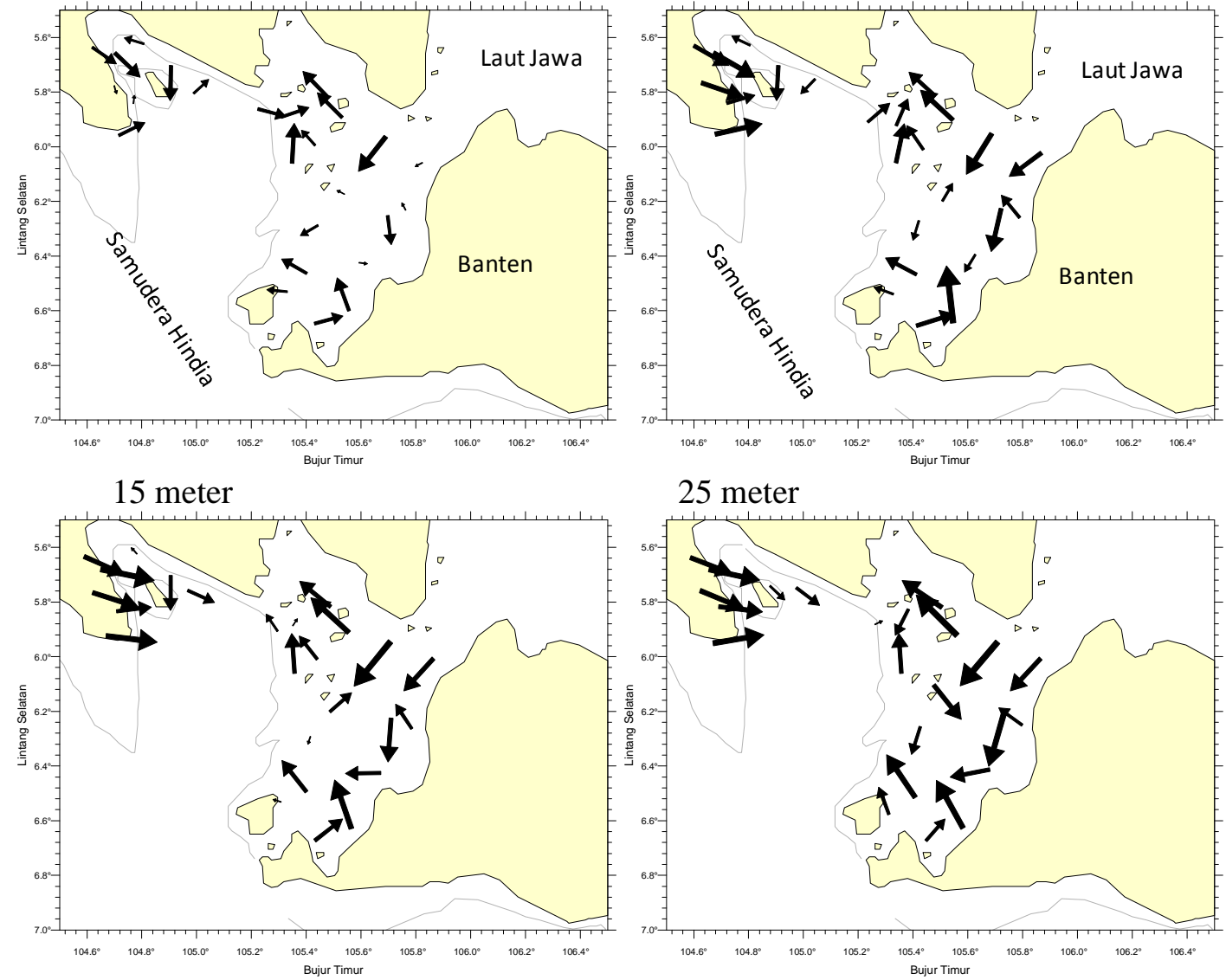

25 meter
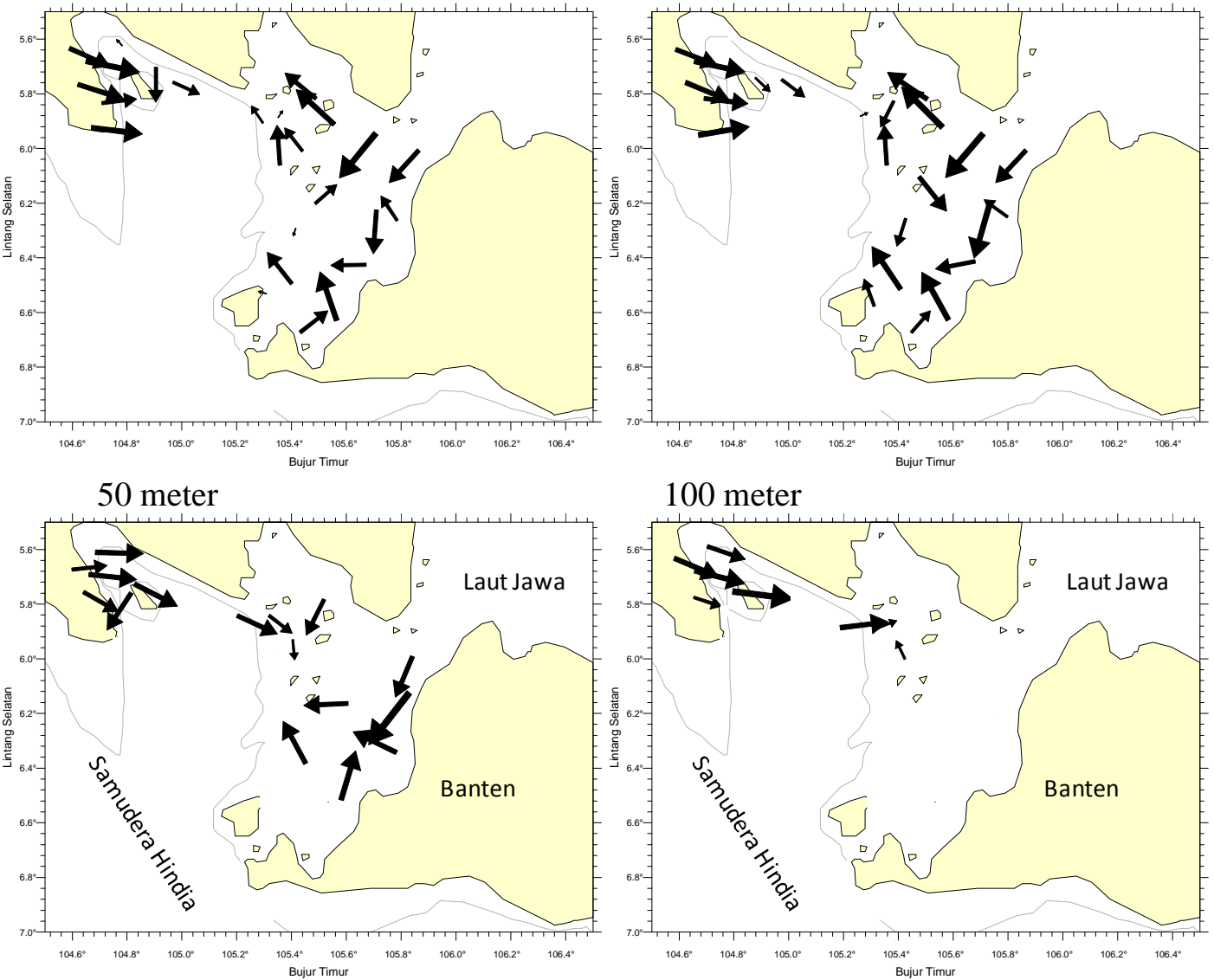

Gambar 6. Pola sebaran arah dan kecepatan arus setiap strata kedalaman di perairan Selat Sunda pada bulan Juni-Juli 2010

Figure 6. Direction and velocity of current by depth stratification in Sunda Strait waters on June-July, 2010 
Tabel 1. Nilai kecerahan air laut tiap stasiun hasil pengukuran Secchi disk di perairan Selat Sunda pada bulan JuniJuli 2010

Table 1. Water transparency measured by Secchi dish in Sunda Strait on June-July 2010

\begin{tabular}{cccccccc}
\hline Sta & Waktu & Kedalaman $(\mathbf{m})$ & Kecerahan $(\mathbf{m})$ & Sta & Waktu & Kedalaman $(\mathbf{m})$ & Kecerahan $(\mathbf{m})$ \\
\hline 1 & $13: 18$ & 43 & 14 & 14 & $17: 48$ & 366 & - \\
2 & $16: 05$ & 78 & 14 & 15 & $18: 23$ & 434 & - \\
3 & $19: 14$ & 82 & - & 16 & $19: 59$ & 314 & - \\
4 & $8: 47$ & 110 & 11 & 17 & $22: 45$ & 240 & - \\
5 & $12: 16$ & 73 & 10 & 18 & $6: 15$ & 22 & - \\
6 & $10: 39$ & 117 & 8 & 19 & $8: 48$ & 294 & 20 \\
7 & $13: 23$ & 33 & 9 & 20 & $11: 42$ & 107 & 9 \\
8 & $16: 12$ & 89 & 7 & 21 & $14: 39$ & 39 & 6 \\
9 & $19: 50$ & 36 & - & 22 & $16: 20$ & 69 & 6 \\
10 & $14: 28$ & 50 & 7 & 23 & $17: 51$ & 24 & - \\
11 & $16: 48$ & 84 & 8 & 24 & $20: 15$ & 28 & - \\
12 & $11: 24$ & 208 & 15 & 25 & $21: 20$ & 28 & - \\
13 & $14: 55$ & 293 & 15 & & & & \\
\hline
\end{tabular}

\section{BAHASAN}

\section{Dinamika Massa Air}

Massa air Samudera Hindia terlihat lebih dominan berada di perairan Teluk Semangka dibandingkan dengan massa air yang terdapat di sekitar gugusan Pulau Rakata, kejadian ini ditunjukkan dengan nilai sebaran salinitas yang lebih tinggi dan temperatur yang lebih rendah di perairan ini. Nilai sebaran salinitas yang lebih rendah di bagian utara perairan gugusan Pulau Rakata, akibat pengaruh massa air Laut Jawa (bersalinitas lebih rendah) yang kemudian bercampur dengan massa air Samudera Hindia. Hal ini dapat dibuktikan dengan melihat pola arus yang menunjukkan adanya dorongan arus yang kuat dari arah utara pada setiap strata lapisan kedalaman di perairan ini. Massa air pencampuran salinitas rendah dari Laut Jawa dengan massa air oseanik dengan salinitas tinggi dari Samudera Hindia pada musim timur, teridentifikasi dari analisa spektral panjang gelombang visible sensor satelit SeaWiFs seperti dilaporkan Hendiarti et al, (2005) dan Amri et al. (2006), bahwa posisinya berkaitan erat kekuatan dorongan arus. Apabila dorongan arus dari Laut Jawa relatif kuat, massa air ini akan terdorong jauh ke selatan. Dalam penelitian ini terlihat keberadaan massa air pencampuran tersebut berada di batas perairan dalam dengan paparan (slope) sekitar Kepulauan Rakata. Sementara pada sisi bagian timur, terlihat dorongan massa air hangat dari Laut Jawa yang mendesak dari arah pantai ke bagian tengah, sehingga massa air di lepas pantai Labuan dan bagian utara Pulau Panaitan didominansi oleh massa air dengan SPL tinggi (hangat). Dari sini terlihat masuknya massa air Samudera Hindia ke Selat Sunda melalui sisi pantai selatan Lampung dan aliran massa air Laut Jawa dominan berada di sisi pantai barat Banten.

\section{Indikasi Upwelling}

Selama penelitian berlangsung, terlihat adanya fenomena upwelling, yang indikasinya ditemukan di perairan Teluk Semangka dan sekitar gugusan Pulau Rakata. Pada daerah tersebut suhu laut lebih rendah dan salinitas lebih tinggi dibanding daerah lainnya. Proses upwelling yang terjadi di lokasi ini merupakan pergerakan massa air dari lapisan dalam yang naik ke permukaan. Massa air dari lapisan dalam memiliki temperatur yang lebih rendah dan salinitas yang lebih tinggi dibandingkan lapisan permukaan.

Terjadinya upwelling di Selat Sunda terkait dengan bentuk topografi dasar laut dan pergerakan arus pada lapisan dalam. Dari hasil pengukuran arus yang menunjukkan kecepatan arus yang berasal dari Samudera Hindia pada lapisan dalam lebih kuat dari pada arus di bagian permukaan. Dorongan arus kuat dari Samudera Hindia inilah yang memicu terjadinya upwelling di sekitar daerah tubir, indikasinya terlihat dari nilai sebaran SPL dan salinitas permukaan seperti tergambar pada sebaran mendatar suhu dan salinitas (Gambar 5).

Gambaran topografi Selat Sunda menunjukkan bahwa perairan ini memiliki gradasi kedalaman dari arah timur laut ke arah barat laut. Di bagian utara selat, kedalaman laut hanya sekitar $40 \mathrm{~m}$, kemudian berangsur-angsur dasar laut menurun ke arah barat daya dengan kedalaman laut sekitar 75-100 m. Selanjutnya, semakin ke arah barat daya, dasar laut tiba-tiba menurun sehingga kedalaman laut menjadi 
sekitar 700-1.200 m (Anonimus, 2002 dalam Amri et al., 2006). Dengan demikian, maka pada bagian tengah perairan terdapat daerah tubir sebagai batas dasar perairan dangkal dengan perairan dalam, yang polanya memanjang utara selatan.

Dari hasil penelitian suhu dan salinitas secara in-situ seperti dilaporkan Muripto et al. (2000), upwelling di Selat Sunda ditemukan saat musim timur dan musim peralihan2. Adanya fenomena upwelling pada lokasi ini juga dapat diamati dari data penginderaan jauh satelit sensor visible seperti dilaporkan Hendiarti, et al. (2005) dan Amri et al. (2006). Indikasinya terlihat dari peningkatan sebaran klorofil-a akibat pengkayaan nutrien yang identik dengan peningkatan produktivitas primer (kesuburan perairan).

\section{Sebaran dan Kelimpahan Fitoplankton}

Rendahnya tingkat kecerahan pada perairan dekat pantai terutama di perairan pesisir barat Banten, terkait dengan tingginya sebaran fitoplankton pada perairan ini. Faktor-faktor penyebab tingginya penyebaran plankton antara lain arus dan nutrien. Asupan massa air dari muaramuara sungai di pesisir barat Banten seperti Labuan dan sekitarnya membawa nutrien sehingga memperkaya kesuburan perairan di lokasi ini. Sebaran spasial kelimpahan fitoplankton hasil survei eksplorasi pada bulan Juni-Juli seperti terlihat pada Gambar 7. Kelimpahan tertinggi berada pada stasiun 9 dengan nilai $1.029 .365 \mathrm{sel} /$ liter, sedangkan terendah ada di stasiun 13 dengan nilai 57.475 sel/liter. Kelimpahan fitoplankton yang cukup tinggi terdapat di perairan bagian barat Banten sepanjang barat Anyer, Labuan sampai Citeureup. Sementara kelimpahan terendah terdapat di perairan sekitar Ujung Kulon dan bagian dalam Teluk Semangka. Secara alamiah fitoplankton tersebar di zona eufotik, dari lapisan permukaan hingga kedalaman air dimana sinar matahari masih dapat mencapainya dan proses fotosintesis dapat berlangsung dengan pola dimana kelimpahan maksimum umumnya terdapat pada kedalaman 20-30 m (Mann \& Lazier, 1991; Graham, 1993). Sampling di Selat Sunda hanya dilakukan di bagian permukaan saja. Pengambilan contoh pada kedalaman yang berbeda diperkirakan akan diperoleh hasil yang berbeda pula.

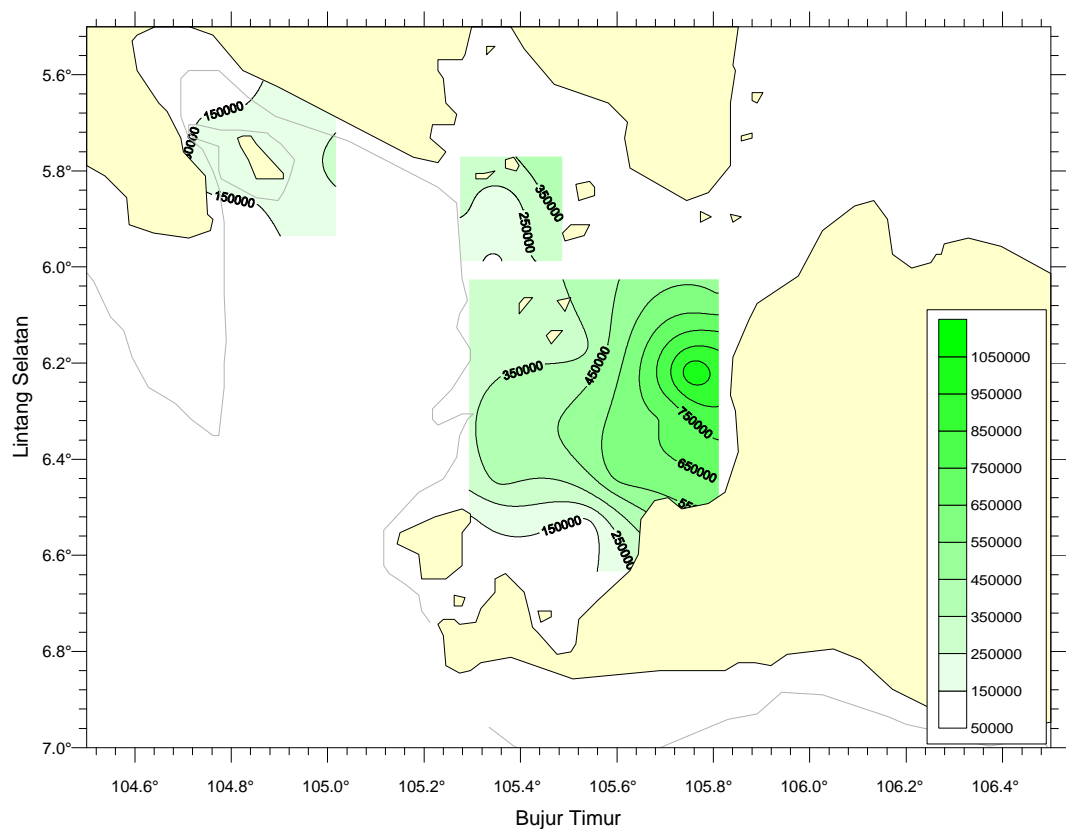

Gambar 7. Sebaran kelimpahan fitoplankton pada stasiun-stasiun sampling di perairan Selat Sunda pada bulan JuniJuli 2010

Figure 7. Distribution of phytoplankton abundant in Sunda Strait waters on June-July, 2010

Dari hasil pengukuran kelimpahan plankton ini dapat dinyatakan bahwa upwelling yang terjadi pada bulan JuniJuli sekitar perairan tubir di bagian tengah selat, tampaknya belum memberi dampak yang signifikan terhadap pengkayaan nutrien di perairan ini, sehingga kelimpahan fitoplankton masih belum mengalami peningkatan yang signifikan. Upwelling yang terjadi di Selat Sunda pada bulan Juni-Juli masih berada pada proses tahap awal. Hal ini sesuai dengan hasil pengamatan Hasyim et al., 1995; Hendiarti et al., 2005 dan Amri et al., 2006 melalui sensor visible citra SeaWiFs yang menyatakan puncak upwelling di Selat Sunda terjadi pada bulan Agustus terpantau dari tingginya nilai sebaran klorofil-a saat itu.

Komposisi jenis, keanekaragaman (H) dan keseragaman (E) fitoplankton ditampilkan pada Gambar 8. 
Ada dua kelas utama yang menyusun fitoplankton hasil sampling di Selat Sunda yaitu Bacillariophyceae dan Dinophyceae, dimana Bacillariophyceae adalah yang paling dominan mencapai $98,5 \%$ dan sisanya adalah Dinophyceae (1,49\%). Kelas Bacillariophyceae terdiri atas 19 jenis dengan jenis dominan Chaetoceros sp. dan Hyalodiscus sp. sebagai yang terendah. Sedangkan kelas Dinophyceae tersusun atas 7 spesies yang didominasi oleh Ceratium sp. Nilai indeks komunitas yang ditunjukkan antar stasiun cukup bervariasi. Nilai indeks keanekaragaman $(\mathrm{H})$ tertinggi yaitu 2.22 terdapat pada stasiun 20 yang berada pada daerah tubir (selatan Pulau Rakata), merupakan lokasi dimana ditemukannya indikator massa air upwelling (SPL rendah dan salinitas tinggi). Sedangkan yang terendah adalah 0,84 terdapat pada stasiun 14 (Teluk Semangka). Kelimpahan fitoplankton dengan keanekaragaman yang tinggi di lokasi upwelling menandakan bahwa peningkatan nutrien akibat upwelling mendukung bagi perkembangan fitoplankton. Untuk nilai indeks keseragaman $(\mathrm{E})$, yang tertinggi ada pada stasiun 22 dengan nilai 0,8 sedangkan terendah ada pada stasiun 15 dengan nilai 0,38 .

Indeks keanekaragaman $(\mathrm{H})$ dan keseragaman $(\mathrm{E})$ fitoplankton

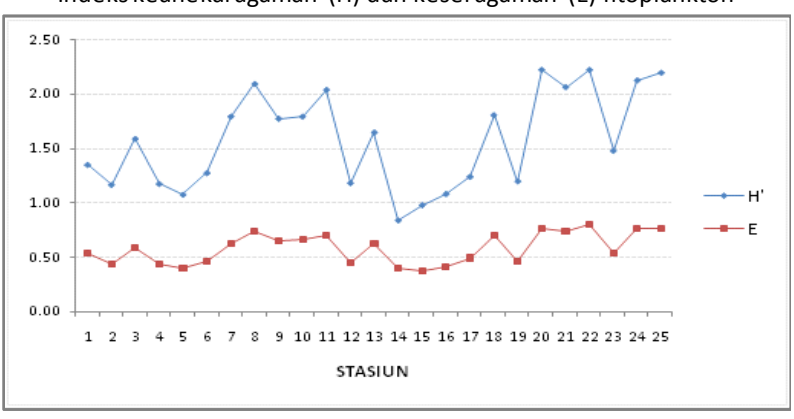

Gambar 8. Indeks keanekaragaman (H) dan keseragaman (E) fitoplankton di perairan Selat Sunda pada bulan Juni-Juli 2010

Figure 8. Diversity index $(H)$ and evenness index $(E)$ of phytoplankton in Sunda Strait waters on June-July, 2010

Penelitian Amri (2008) menyebutkan adanya keterkaitan antara kondisi oseanografi dan peningkatan kesuburan perairan akibat upwelling dengan kelimpahan ikan pelagis di perairan Selat Sunda. Pola keterkaitan tersebut berbeda berdasarkan musim, seperti halnya hasil penelitian Muripto et al. (2000).

Terdapat korelasi yang kuat antara peningkatan kosentrasi kesuburan perairan akibat terjadinya upwelling pada musim timur didukung kondisi SPL dan salinitas dengan peningkatan hasil tangkapan ikan pelagis (Amri, 2008). Ikan-ikan oseanik seperti banyar (Rastreliger kanagurta), layang (Deapterus macrosoma) dan lemuru (Sardinella sp.) mendominasi hasil tangkapan pada musim timur. Ketika itu, massa air yang dominan di perairan Selat
Sunda adalah massa air oseanik (salinitas tinggi) akibat peristiwa upwelling dan aliran massa air dominan berasal dari Samudera Hindia. Sebaliknya, ikan-ikan neritic seperti tongkol (Euthynnus affinis) dan ternggiri (Scomberomorus sp.) hasil tangkapannya melimpah pada musim barat. Ketika itu massa air di perairan Selat Sunda bersalinitas rendah dan aliran massa air dominan berasal dari Laut Jawa. Lokasi fishing ground nelayan mini purse seine penagkap ikanikan pelagis kecil di Selat Sunda seperti dilaporkan Muripto et al. (2000) ternyata identic dengan lokasi-lokasi pengkayaan klorofil-a (peningkatan fitoplankton) yang ditemukan dalam penelitian ini. Lokasi tersebut umumnya berada pada daerah tubir, tempat dimana indikasi upwelling ditemukan (SPL rendah dan salinitas tinggi) dan nilai indeks keanekaragaman $(\mathrm{H})$ fitoplankton tertinggi yaitu pada stasiun 20 yang berada di selatan Pulau Rakata.

\section{KESIMPULAN}

Nilai sebaran Suhu Permukaan Laut (SPL) perairan Selat Sunda pada musim timur bervariasi, lebih hangat mendekati pesisir barat Banten terkait pengaruh daratan (river discharge) dan massa air dangkal Laut Jawa, sebaliknya lebih dingin ke arah samudera. Upwelling di bagian tengah selat disebabkan benturan arus kuat dari Samudera Hindia pada daerah tubir lapisan dalam. Intensitasnya lemah pada bulan Juni-Juli, menandakan masih fase awal dari proses terjadinya upwelling di perairan ini. Nilai indeks keanekaragaman $(\mathrm{H})$ dan keseragaman $(\mathrm{E})$ fitoplankton yang tertinggi berasosiasi dengan lokasi dimana massa air upwelling ditemukannya. Kelimpahan fitoplankton dengan keanekaragaman yang tinggi di lokasi upwelling menandakan bahwa peningkatan nutrien akibat upwelling mendukung bagi perkembangan fitoplankton. Kejadian ini bersamaan dengan meningkatnya hasil tangkapan ikan banyar, layang dan lemuru pada musim ikan di Selat Sunda.

\section{PERSANTUNAN}

Tulisan ini bagian dari Kegiatan Penelitian BPPL 2010 tentang Kajian Kelimpahan Ikan Pelagis dengan Kondisi Oseanografis di Perairan Selat Sunda WPP 572. Ucapan terima kasih penulis sampaikan kepada seluruh Tim Peneliti dan ABK Kapal Riset Sardinella yang telah mendukung penelitian ini.

\section{DAFTAR PUSTAKA}

Adnan. 2003. Eutrofikasi dan akibatnya bagi kehidupan di perairan indonesia alternatif dampak berbagai kegiatan pembangunan kota metropolitan. Orasi Pengukuhan Ahli Peneliti Utama Bidang Planktonologi. Puslit Oseanonografi-Lembaga Ilmu Pengetahuan Indonesia. Jakarta 15 September 2003. 
Amri, K. 2008. Analisis Hubungan Kondisi Oseanografi dengan Fluktuasi Hasil Tangkapan Ikan Pelagis di Selat Sunda. Pusat Penelitian Pengelolaan Perikanan dan Konservasi Sumber Daya Ikan. Balitbang Kelautan dan Perikanan. Jurnal Penelitian Perikanan Indonesia. 14 (1). 55-65.

Amri K., D. Manurung, \& V.P. Siregar. 2007. Dinamika kondisi oseanografi musiman perairan Selat Sunda dari analisis data multitemporal. Jurnal Penelitian Perikanan Indonesia. 13 (3). 191-199.

Amri, K., Suwarso \& Herlisman. 2006. Kondisi Hidrologis dan Kaitannya dengan Hasil Tangkapan Ikan Malalugis (Decapterus macarellus) di Perairan Teluk Tomini. Jurnal Penelitian Perikanan Indonesia. 12 (3). 183-193.

Birowo, S. 1983. Hydro-oceanographic condition of the Sunda Strait: A review. Proceding of Symposium on $100^{\text {th }}$ Year Development of Krakatau and Its Souronding. Lembaga Ilmu Pengetahuan Indonesia. Jakarta. 8 hal.

Birowo, S. \& Uktolseja. 1981. Oceanographics feature of Sunda Strait. Proceeding of Workshop and Coastal Resources Management of the Krakatau and Sunda Strait Report. Indonesia. Jakarta. 54-75.

Graham, W.M., 1993. Spatio-temporal scale assessment of an 'upwelling shadow' in northern Monterey Bay, California. Estuaries 16. 83-91.

Hasyim, B., K. Amri \& M. Hartuti (1995). Pemanfaatan data penginderaan jauh noaa-avhrr untuk pengamatan pola arus laut dan daerah potensi penangkapan ikan. Prosiding Konvensi Nasional Pembangunan Benua Maritim Indonesia. BPPT. 149 - 163.

Hendiarti, N., Suwarso, A. Adrian, K. Amri, R. Andiastuti, I.B. Wahyono \& S. I. Sachoemar. 2005. Seasonal variation of pelagic fish catch arround Java. Oceanography Society Jour Rockvile, MD, USA. 18 (4). 112-123.

Laevastu, T \& M. L. Hayes, 1981. Fisheries Ocenography and Ecology. Fishing News Books Ltd. 199 p.
Ludwig JA, \&JF Reynolds. 1988. Statistical Ecology. New York: J. Wiley. 202 p.

Mann, K. H. \& Lazier, J. R. N. (1991) Dynamics of marine ecosystems. Biological-physical interactions in the Oceans. Blackwell Scientific Publishers, Boston. 394 p.

Muripto, I., D. Manurung, \& Rahadian. 2000. Oceanographic features that define the Sunda Strait upwelling related to hot spot area. The Proceedings of the JSP-DGHE International Symposium on Fisheries Science in Tropical Area. Bogor. Indonesia. 23-31.

Nontji, A. 1987. Laut Nusantara. Penerbit Djambatan Jakarta. 367 hal.

Odum, E.P., 1971. Fundamentals of ecology. 3nd Ed., W.B. Saunders Company, Philadelphia. 574 p.

Pielou, E.C. 1976. Mathematical Ecology. 2nd ed. WileyInterscience Publishers, New York. 385 p.

Pralebda, G.D. \& Z. Suyuti, 1983. Teknik teledeteksi dengan menggunakan satelit cuaca GMS-1 untuk menunjang industri perikanan laut di Indonesia. Majalah LAPAN. 27.3-10.

Thomas, C. R. (1997), Identifying marine phytoplankton. San Diego: Academia Press. 858 p.

Tisch, T. D., S. R. Ramp, \& C. A. Collins. 1992. Observations of the geostropic current and water mass characteristic off point sur. Calivornia. From May 1998 through November 1989. Journal Geophys. Res. 97 (C8): 12 355-12555.

Wyrtki, K. 1961. Physical oceanography of the Southeast Asian water. NAGA Report vol 2. Scripps inst. Oceanography. The University oh California).

Yamaji, I., 1979, Illustrations of the marine plankton of Japan, Enlarged \& Revised edition, Hoikusha Publishing Co., Ltd. Osaka, Jepang: 350 p. 